\title{
Properties and antioxidant activity of water-soluble iron catalysts with Schiff base ligands. Comparison with their manganese counterparts
}

\author{
Verónica A. Daier, ${ }^{\text {a }}$ Claudia M. Palopoli, ${ }^{\text {a }}$ Christelle Hureau, ${ }^{\text {b Ariel De Candia, }}{ }^{\text {c }}$ \\ and Sandra R. Signorella ${ }^{a, *}$ \\ ${ }^{a}$ Facultad de Ciencias Bioquímicas y Farmacéuticas - Universidad Nacional de Rosario, IQUIR \\ (Instituto de Química Rosario) - CONICET, Suipacha 531, S2002LRK Rosario, Argentina \\ ${ }^{b}$ CNRS; LCC (Laboratoire de Chimie de Coordination); 205, route de Narbonne, F-31077 \\ Toulouse, France and Université de Toulouse; UPS, INPT; LCC; F-31077 Toulouse, France \\ ${ }^{c}$ Departamento de Química Inorgánica, Analítica y Química Física / INQUIMAE-CONICET, \\ Facultad de Ciencias Exactas y Naturales, Universidad de Buenos Aires, Ciudad Universitaria, \\ Pabellón 2, Buenos Aires, C1428EHA, Argentina \\ E-mail: signorella@iquir-conicet.gov.ar
}

\section{Dedicated to Professors Manuel González Sierra, Rita H. Rossi, Julio C. Podestá and Oscar S. Giordano for their outstanding contribution to the Organic Chemistry in Argentina}

\begin{abstract}
Three new iron complexes $\mathrm{Na}_{2}\left[\mathrm{Fe}\left(5-\mathrm{SO}_{3}\right.\right.$-salpn $\left.)\left(\mathrm{H}_{2} \mathrm{O}\right)_{2}\right] \mathrm{OH} \cdot 4 \mathrm{H}_{2} \mathrm{O} \quad\left(\mathbf{1} \cdot 4 \mathrm{H}_{2} \mathrm{O}\right), \quad \mathrm{Na} 2\left[\mathrm{Fe}\left(5-\mathrm{SO}_{3}\right.\right.$ salpnOH $\left.)\left(\mathrm{H}_{2} \mathrm{O}\right)_{2}\right] \mathrm{Cl} \cdot 7 \mathrm{H}_{2} \mathrm{O} \quad\left(\mathbf{2} \cdot 7 \mathrm{H}_{2} \mathrm{O}\right) \quad$ and $\quad \mathrm{Na}_{2}\left[\mathrm{Fe}_{2}\left(5-\mathrm{SO}_{3}\right.\right.$-salpentO $)(\mu-\mathrm{OAc})(\mu-$ $\left.(\mathrm{OH})\left(\mathrm{H}_{2} \mathrm{O}\right)_{2}\right] \mathrm{OH} \cdot 3 \mathrm{H}_{2} \mathrm{O}\left(3 \cdot 3 \mathrm{H}_{2} \mathrm{O}\right)$, where 5- $\mathrm{SO}_{3}$-salpn = 1,3-bis $\left(5-\mathrm{SO}_{3}\right.$-salicylidenamino $)$ propane, 5- $\mathrm{SO}_{3}$-salpnOH = 1,3-bis(5- $\mathrm{SO}_{3}$-salicylidenamino)propan-2-ol and 5- $\mathrm{SO}_{3}$-sapentOH = 1,5-bis(5$\mathrm{SO}_{3}$-salicylidenamino)pentan-3-ol, have been obtained and characterized. The ligands tune the redox potential of $\mathbf{1}$ and $\mathbf{2}$ within the range required for superoxide dismutase activity, with $\mathbf{2}$ being less reactive as a result of the formation of an inactive dimer. Complex $\mathbf{3}$ looses acetate and converts into a $\mu$-oxo- $\mathrm{Fe}_{2}$ species responsible for its catalase activity. The more negative reduction potentials of $\mathbf{1}-\mathbf{3}$ and their lower stability result in rates of superoxide and peroxide disproportionation 10- to 100-times slower than those of the Mn counterparts.
\end{abstract}

Keywords: Water soluble Fe complexes, Schiff base ligands, antioxidant activity 


\section{Introduction}

Peroxide and superoxide generated in the respiratory chain are usually well managed by aerobic organisms that employ superoxide dismutases (SODs) and catalases (CATs) to overcome the deleterious effects of these oxidants. ${ }^{1,2}$ In many chronic inflammatory and degenerative diseases, the production of $\mathrm{O}_{2}{ }^{2-}$ and $\mathrm{O}_{2}{ }^{--}$is enhanced over the inactivating capability of CATs and SODs, thereby resulting in cell injury. ${ }^{3}$ In this context, pharmacological research has pointed at the development of low molecular weight CAT and SOD mimics as therapeutic agents for the prevention of oxidative stress injuries. The active site of SODs may contain one pentacoordinated $\mathrm{Fe}$ or $\mathrm{Mn}$ ion in a $\mathrm{N}_{3} \mathrm{O}_{2}$ environment to dismutate $\mathrm{O}_{2}{ }^{-{ }^{-1}}$, whereas CATs catalyze the disproportionation of $\mathrm{H}_{2} \mathrm{O}_{2}$ by using an $\mathrm{Fe}$ protoporphyrin IX or a bis( $\mu$-oxo)(hydroxo)- $\mu$ carboxylate dimanganese structural unit as the active site. ${ }^{2}$ Therefore, to mimic these metallosites it is essential to employ ligands that reproduce the singularities of the metal environment in the biosite as well as the electronic properties that control catalysis.

To disproportionate $\mathrm{O}_{2}{ }^{--}$and $\mathrm{O}_{2}{ }^{2-}$ efficiently, the reduction potential of SOD and CAT is fine-tuned to values much lower than that of the $\mathrm{M}^{3+}{ }_{\text {(ac) }} / \mathrm{M}^{2+}{ }_{\text {(ac) }}$ couple. ${ }^{4}$ However, in spite of the large number of $\mathrm{Mn}$ and Fe complexes that have shown CAT and/or SOD activity, ${ }^{5,6}$ only a few studies have been performed on the ability of the ligand to control the redox potential and the divergence between $\mathrm{Mn}$ and $\mathrm{Fe}$ redox potentials in model compounds. ${ }^{7}$ These aspects are essential for the rational design of more efficient catalytic antioxidants with improved stability under physiological conditions. In this context, we have synthesized, characterized and evaluated the electrochemical properties and $\mathrm{SOD} / \mathrm{CAT}$ activity of water soluble mono- and dinuclear $\mathrm{Fe}$ complexes with the ligands: 1,3-bis(5- $\mathrm{SO}_{3}$-salicylidenamino)propan-2-ol $\left(5-\mathrm{SO}_{3}\right.$ - $\left.\mathrm{salpnOH}\right), 1,3-$

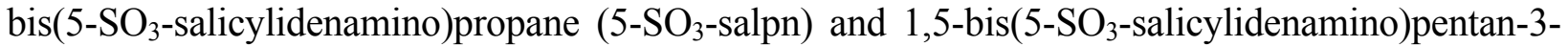
ol (5- $\mathrm{SO}_{3}$-salpentOH), and compared the redox properties and antioxidant activity of the new $\mathrm{Fe}$ complexes to those of the isostructural Mn counterparts.

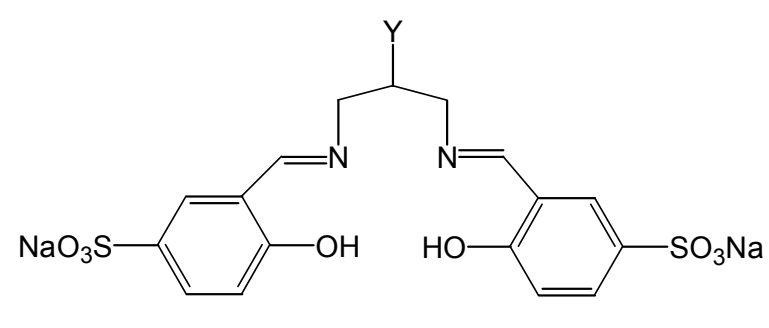

5- $\mathrm{SO}_{3}-\mathrm{salpn}(\mathrm{OH})$

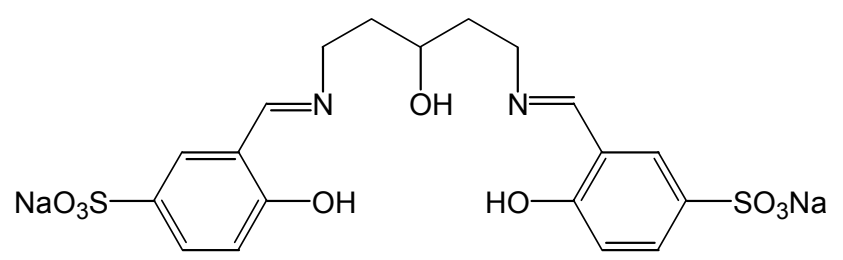

5- $\mathrm{SO}_{3}$-salpentOH

Figure 1. Ligands used in this work. $\mathrm{Y}=\mathrm{H}$ in 5-SO 3 -salpn and $\mathrm{Y}=\mathrm{OH}$ in 5- $\mathrm{SO}_{3}-\mathrm{salpnOH}$. 


\section{Results and Discussion}

\section{Obtention and characterization of the catalysts}

The three polydentate symmetric Schiff base ligands, 5- $\mathrm{SO}_{3}$-salpnOH, 5- $\mathrm{SO}_{3}$-salpn and 5- $\mathrm{SO}_{3}$ salpentOH, were employed to prepare water soluble iron complexes of different nuclearity. While the length of the aliphatic chain between the imino groups in these ligands controlled the nuclearity of the resulting complex, introduction of $-\mathrm{SO}_{3}{ }^{-}$as aromatic substituent led to complexes suitable for antioxidant activity studies in water solution. This is an important point, because most studied complexes are slightly soluble in water or lose activity under the conditions of antioxidant activity assays. ${ }^{8}$

Complexes $\mathrm{Na}_{2}\left[\mathrm{Fe}\left(5-\mathrm{SO}_{3}\right.\right.$-salpn $\left.)\left(\mathrm{H}_{2} \mathrm{O}\right)_{2}\right] \mathrm{OH} \cdot 4 \mathrm{H}_{2} \mathrm{O}\left(\mathbf{1} \cdot 4 \mathrm{H}_{2} \mathrm{O}\right)$ and $\mathrm{Na}_{2}\left[\mathrm{Fe}\left(5-\mathrm{SO}_{3}\right.\right.$-salpnOH) $\left.\left(\mathrm{H}_{2} \mathrm{O}\right)_{2}\right] \mathrm{Cl} \cdot 7 \mathrm{H}_{2} \mathrm{O}\left(\mathbf{2} \cdot 7 \mathrm{H}_{2} \mathrm{O}\right)$ were prepared from 1:1 mixtures of the ligand with $\mathrm{FeCl}_{3}$ in methanol and the analytical results show that the two complexes retain two sodium ions per complex molecule in the solid state, but only complex $\mathbf{2}$ contains chloride. The IR spectra of $\mathbf{1}-\mathbf{2}$ are very close (figure S1) and exhibit strong imine/phenolate absorptions at 1630-1623/1545-1538 $\mathrm{cm}^{-1}$ and two strong bands at 1110 and $1028 \mathrm{~cm}^{-1}$ attributable to the anti-symmetric and symmetric stretching modes of the $-\mathrm{SO}_{3}{ }^{-}$groups. Comparison of the IR spectra of $\mathbf{1}-\mathbf{2}$ with those of the well characterized $\mathrm{Mn}$ complexes formed with the same ligands ${ }^{9}$ (figure 1S) evidences the "fingerprint" pattern of 5- $\mathrm{SO}_{3}$-salpn and 5- $\mathrm{SO}_{3}$-salpnOH coordinated to the metal and confirms the similar structures of $\mathrm{Mn}$ and $\mathrm{Fe}$ complexes obtained with the ligands acting through the $\mathrm{N}_{2} \mathrm{O}_{2}$ donor set.
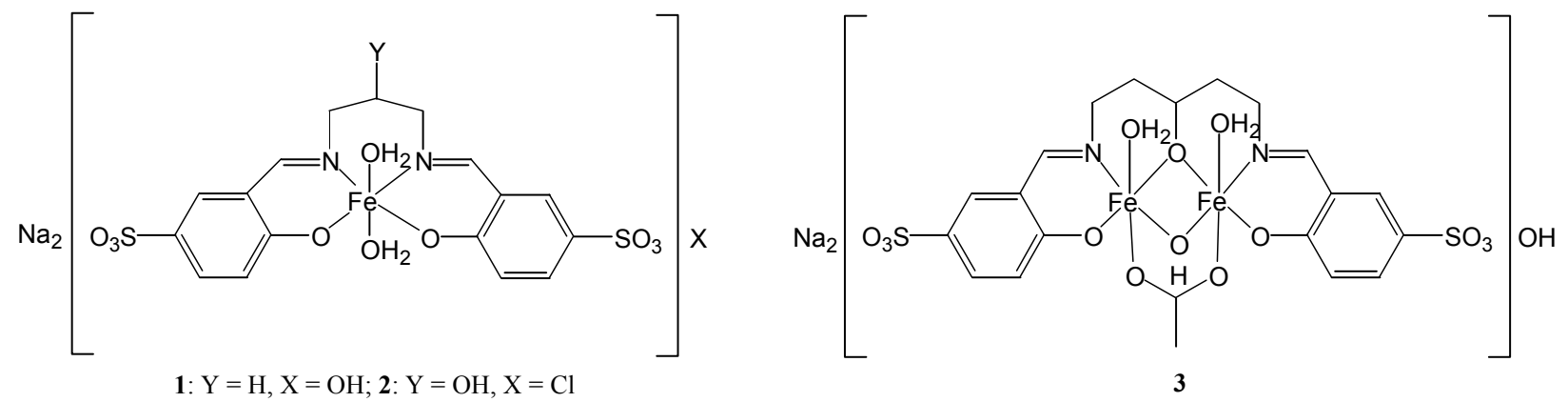

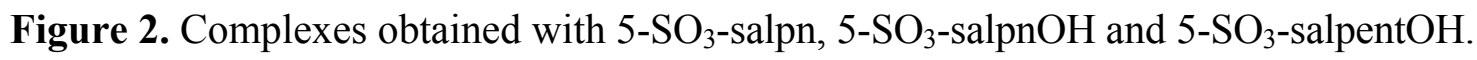

The $\mathrm{N}_{2} \mathrm{O}_{3}$ pentadentate symmetric ligand, 5- $\mathrm{SO}_{3}$-salpentOH, which provide an alkoxo oxygen for the endogenous bridging of two metal ions and two arms with $\mathrm{N}_{2} \mathrm{O}_{2}$ chelating donor sets, was reacted with 2 equivalents of $\mathrm{Fe}(\mathrm{OAc})_{2}$ to afford the dinuclear Fe ${ }^{\mathrm{III}}$ complex $\mathrm{Na}_{2}\left[\mathrm{Fe}_{2}(5\right.$ $\mathrm{SO}_{3}$-salpentO) $\left.(\mu-\mathrm{OAc})(\mu-\mathrm{OH})\left(\mathrm{H}_{2} \mathrm{O}\right)_{2}\right] \mathrm{OH} \cdot 3 \mathrm{H}_{2} \mathrm{O} \quad\left(3 \cdot 3 \mathrm{H}_{2} \mathrm{O}\right)$. The IR spectrum of complex 3 (figure S2) exhibits strong imine and phenolate absorptions between 1635 and $1537 \mathrm{~cm}^{-1}$ that are shifted by $\approx 15 \mathrm{~cm}^{-1}$ from those in the free ligand due to the coordination of the metal to these groups and shows absorption peaks at $1552 \mathrm{~cm}^{-1}$ and $1427 \mathrm{~cm}^{-1}$, that identify the anti-symmetric 
and symmetric stretching vibrations of the syn-syn 1,3-bridging acetate. ${ }^{10}$ The separation between the anti-symetric and symmetric absorptions $(\Delta v)$ of $125 \mathrm{~cm}^{-1}$ is diagnostic of 1,3bridging carboxylate. ${ }^{10}$ The assignment was confirmed comparing the IR spectrum of $\mathbf{3}$ with those of $\mathrm{Na}_{2}\left[\mathrm{Fe}_{2}\left(5-\mathrm{SO}_{3} \text {-salpentO) }(\mu-\mathrm{O}) \mathrm{Cl}\left(\mathrm{H}_{2} \mathrm{O}\right)\right]^{11}\right.$ and $\mathrm{Na}\left[\mathrm{Mn}_{2}\left(5-\mathrm{SO}_{3}\right.\right.$-salpentO $)(\mu-\mathrm{OAc})(\mu-$ $\left.\mathrm{OMe})\left(\mathrm{H}_{2} \mathrm{O}\right)\right]^{12}$ (Figure S2). While bands characteristic of carboxylate stretching modes are absent in the IR spectrum of $\mathrm{Na}_{2}\left[\mathrm{Fe}_{2}\left(5-\mathrm{SO}_{3}\right.\right.$-salpentO $\left.)(\mu-\mathrm{O}) \mathrm{Cl}\left(\mathrm{H}_{2} \mathrm{O}\right)\right]$, complex 3 and the diMn complex show the two bands attributable to the bridging acetato anion separated by $125 \mathrm{~cm}^{-1}$, indicating the same mode of bidentate acetato coordination in the two complexes.

Additionally, the IR spectra of compounds $1-3$ display a broad band at $\approx 3400 \mathrm{~cm}^{-1}$ assigned to non-coordinated water molecules.

ESI-mass spectra of complexes $\mathbf{1} \mathbf{- 2}$ in methanol confirmed their chemical composition and showed that both complexes are mononuclear in solution. For complex 1, the parent peak is observed at $\mathrm{m} / \mathrm{z}=494.1(100 \%)$ in the negative mode ESI-mass spectra and originates from the $\left[\mathrm{Fe}\left(5-\mathrm{SO}_{3} \text {-salpn }\right)\right]^{-}$monoanion. Two other minor peaks are also observed at $\mathrm{m} / z=525$ and 534 and correspond to the $\left[\mathrm{Fe}\left(5-\mathrm{SO}_{3} \text {-salpn }\right)(\mathrm{OMe})\right]^{-}$and $\mathrm{Na}\left[\mathrm{Fe}\left(5-\mathrm{SO}_{3} \text {-salpn }\right)(\mathrm{OH})\right]^{-}$anions, respectively. In the case of complex 2 , solubility in methanol was not enough to give a good mass spectrum in the negative mode. Instead, in the positive mode ESI-mass spectrum two peaks at $m / z=563.7$ and 585.7 could be observed, originated from the $\mathrm{H}_{2}\left[\mathrm{Fe}\left(5-\mathrm{SO}_{3}-\mathrm{salpnOH}\right)\left(\mathrm{H}_{2} \mathrm{O}\right)\right.$ $(\mathrm{MeOH})]^{+}$and $\mathrm{NaH}\left[\mathrm{Fe}\left(5-\mathrm{SO}_{3} \text {-salpnOH }\right)(\mathrm{MeOH})\left(\mathrm{H}_{2} \mathrm{O}\right)\right]^{+}$monocations.

The ESI-mass spectrum of $\mathbf{3}$ in methanol confirmed that dinuclearity of the complex is retained in solution. The negative mode mass spectrum of $\mathbf{3}$ is dominated by the peak at $\mathrm{m} / \mathrm{z}=$ 683 corresponding to the monoanion $\left[\mathrm{Fe}_{2}\left(5-\mathrm{SO}_{3} \text {-salpentO)(MeO)(OAc)}\right]^{-}\right.$, formed by replacement of hydroxide by methanolate originated from the solvent used in the spray experiments. Other minor peaks correspond to $\mathrm{Na}\left[\mathrm{Fe}_{2}\left(5-\mathrm{SO}_{3} \text {-salpentO }\right)(\mathrm{MeO})_{2}(\mathrm{OAc})\right]^{-}(\mathrm{m} / z=$ $737)$ and $\mathrm{Na}\left[\mathrm{Fe}_{2}\left(5-\mathrm{SO}_{3} \text {-salpentO)(MeO)(OAc) }\right)_{2}\right]^{-}(m / z=765)$.

Electronic spectra of complexes $\mathbf{1}-\mathbf{2}$ in aqueous solution consist of a broad band in the visible and a more intense band in the ultraviolet region (shown for $\mathbf{2}$ in figure 3(a)). The charge transfer (CT) bands from the phenolate to the metal have intermediate intensity, appear around $470-510 \mathrm{~nm}$, and are responsible for the red color of these complexes. These transitions can be assigned to a charge transfer from the $p_{\pi}$ orbital of the phenolic oxygen to the $d_{\pi}$ orbital of the iron centre. ${ }^{13}$ The similar spectral pattern of the electronic spectra of the two complexes is consistent with their analogous structure in solution.

The UV-vis spectrum of complex 3 (figure S3(a)) shows very strong electronic absorption bands in the UV and near-UV region (220-370 nm) and a less intense broad shoulder in the visible region (430-550). The absorption bands at 320 and $368 \mathrm{~nm}$ correspond to ligand-centered transitions overlapping with phenolate-to-metal charge-transfer ones. The broad shoulder in the visible region can be assigned as ligand field transitions whose unusually high intensities are due in part to the relaxation of spin restrictions upon antiferromagnetic coupling of the two iron atoms. $^{14}$ 

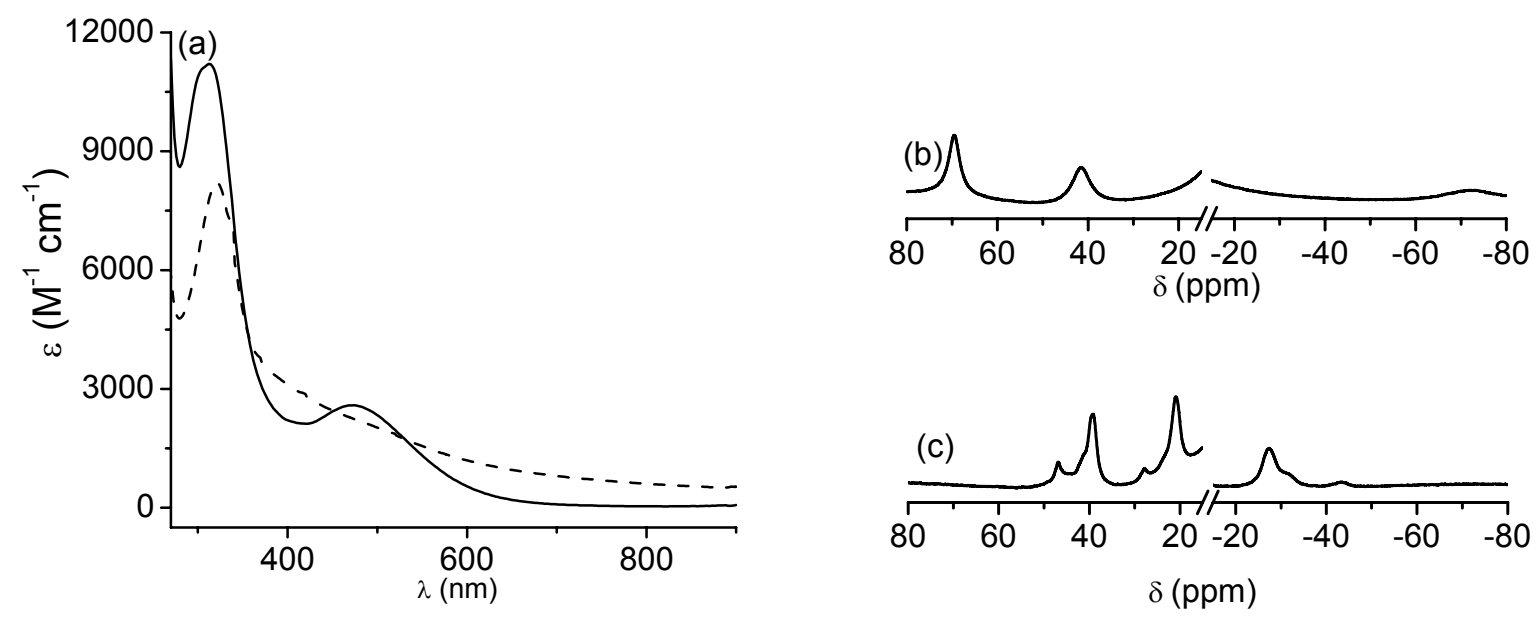

Figure 3. (a) Electronic spectra of aqueous solutions of 2 (-) and $\mathbf{2}+5$ eq NaOH (---). (b) ${ }^{1} \mathrm{H}$ NMR spectra of 1 in $\mathrm{D}_{2} \mathrm{O}$. (c) ${ }^{1} \mathrm{H}$ NMR spectrum of 2 in phosphate buffer of $\mathrm{pH} 7.8$ in $\mathrm{D}_{2} \mathrm{O}$.

Solutions of complexes $\mathbf{1}-\mathbf{2}$ in $\mathrm{D}_{2} \mathrm{O}$, exhibit ${ }^{1} \mathrm{H}$ NMR spectra with features outside the diamagnetic region due to the presence of the $S=5 / 2$ center, with a pattern of ring proton shifts consistent with dominant contact interactions that arise from the delocalization of unpaired spin density onto the symmetrically disposed ligand in the equatorial plane of the complex. ${ }^{15}$ Previous NMR studies on Schiff base Fe $\mathrm{F}^{\text {III }}$ complexes have shown that delocalization of unpaired spin density occurs via a $\pi$ mechanism, resulting in an alternation in the sign of the contact shift exhibited by the protons of the phenolate moieties. ${ }^{16}$ In the present case, the three resonances observed at 69.2, 41.3 and -71.9 ppm for 1 (shown in figure 3(b)) and 67.1, 46.5 and -71 ppm for 2, can be assigned to H4/4', H6/6' and H3/3', respectively. Upon addition of base to an aqueous solution of complex $\mathbf{2}$, resonances of the aromatic ring protons belonging to the original complex slowly disappear and are replaced by a larger number of resonances with lower contact shifts, indicating the starting complex transforms into another one in which the phenolate protons are not longer equivalent (figure 3(c)). In consonance with the decrease of chemical shifts in the paramagnetic NMR spectrum and the increasing number of resonances observed for the aromatic ring protons, the phenolate to $\mathrm{Fe}^{\mathrm{III}} \mathrm{CT}$ transition shifts to higher energy (figure $3(\mathrm{a})$ ). ${ }^{16 \mathrm{~b}}$ This can be explained considering that in basic medium, deprotonation of the alcohol takes place and facilitates complex dimerization with the ligand acting through a $\mathrm{N}_{2} \mathrm{O}_{3}$ donor set. Such a behavior has previously been observed for metal complexes formed with salpnOH, ${ }^{17}$ in which the ligand adopts an asymmetrical disposition around the metal. In this type of dimer, protons of the two phenol moieties are not longer equivalent and phenolate occupies equatorial and axial positions around iron and $\sigma / \pi$ contact interactions should be operative. Besides, antiferromagnetic coupling of the two iron ions in the dimer should explain the smaller chemical shifts. ${ }^{16 a}$ The presence of a stronger axial ligand in the dimer is consistent with a ligand field increase that results in the blue shift of the CT band maxima, such as observed. ${ }^{18}$ 
The ${ }^{1} \mathrm{H}$ NMR spectrum of 3 in $D_{4}$-methanol is shown in figure 4(a). The spectrum is dominated by three broad resonances at 59.7, 38.6 and $-57 \mathrm{ppm}$, assigned to the phenolate protons. This spectral pattern should result from a mechanism of $\pi$-spin delocalization through the $\mathrm{C}$ bonds of the two symmetrically related coordinated phenolate rings. Consequently, three resonances are expected from the two magnetically equivalent terminal phenolate ring protons with an alternating sign pattern of shifts in agreement with the $\pi$-spin-delocalization mechanism. The absence of the $-105 \mathrm{ppm}$ resonance in the spectrum of $\left[\mathrm{Fe}_{2}\left(5-\mathrm{SO}_{3} \text {-salpentO)(O) }\right]^{-11}\right.$ (figure 4(b)) suggests this resonance can be assigned to the acetate methyl protons of $\mathbf{3}$.
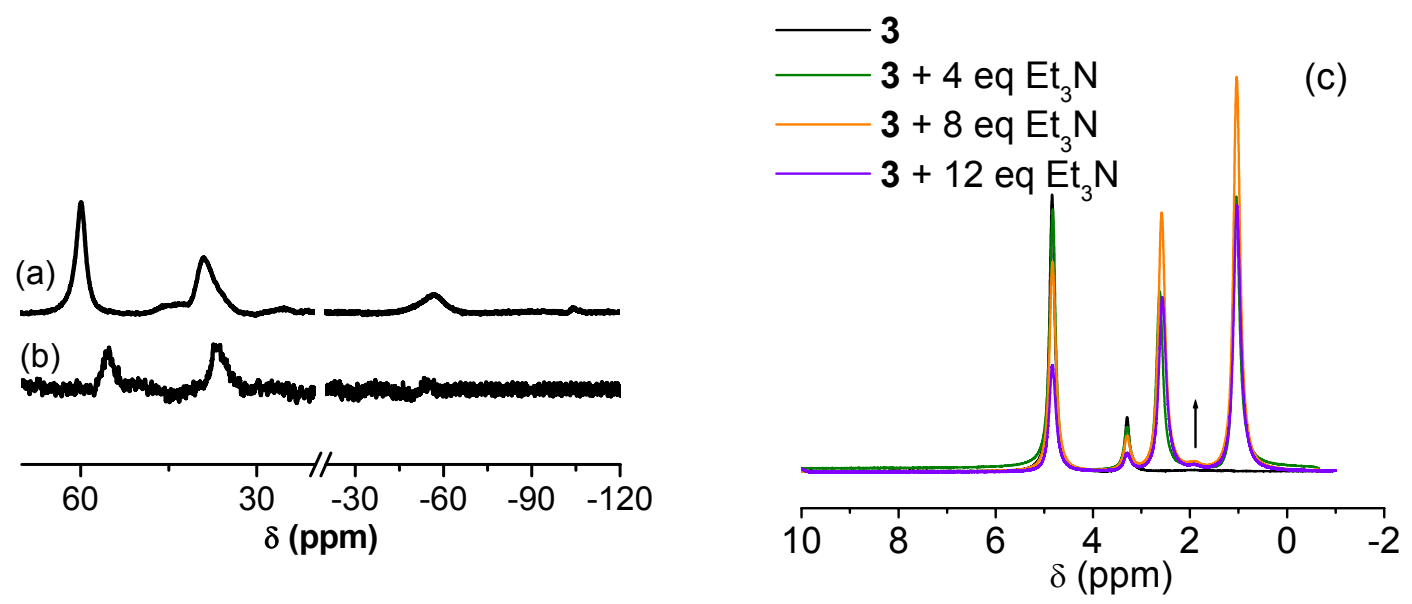

Figure 4. Paramagnetic ${ }^{1} \mathrm{H}$ NMR spectra of 3 (a) and $\left[\mathrm{Fe}_{2}\left(5-\mathrm{SO}_{3} \text {-salpentO)( } \mu-\mathrm{O}\right)\right]^{-}$(b) in $\mathrm{D}_{4^{-}}$ methanol. Diamagnetic ${ }^{1} \mathrm{H}$ NMR spectra of 3 in $\mathrm{D}_{4}$-methanol after addition of increasing amounts of $\mathrm{Et}_{3} \mathrm{~N}$ (c).

Addition of $\mathrm{Et}_{3} \mathrm{~N}$ to the methanol solution of $\mathbf{3}$ results in paramagnetic spectra with smaller chemical shifts. The spectral changes caused by the basic medium suggests conversion of the starting complex into a $\mu$-oxo one in which antiferromagnetic coupling of the two iron ions is favored. Inspection of the diamagnetic region after addition of $\mathrm{Et}_{3} \mathrm{~N}$ shows the appearance of the free acetate resonance at $1.9 \mathrm{ppm}$ (figure 4(c)). The intensity of the acetate peak increases with increasing amounts of $\mathrm{Et}_{3} \mathrm{~N}$, thus implying that conversion into the $\mu$-oxo complex involves acetate dissociation. Electronic spectroscopy provided another piece of evidence supporting conversion into the $\mu$-oxo complex. UV-vis spectra of solutions of complex $3+\mathrm{Et}_{3} \mathrm{~N}$ showed that the band at $320 \mathrm{~nm}$ shifts to $368 \mathrm{~nm}$ and its intensity increases after addition of $\mathrm{Et}_{3} \mathrm{~N}$ (figure S3(a)). Apparition of the red shifted band is concurrent with the decrease of the absorbance at $320 \mathrm{~nm}$ and occurs with an isosbestic point at $335 \mathrm{~nm}$, indicating direct conversion of the initial complex into a new species. The band at $368 \mathrm{~nm}$ may correspond to oxo to $\mathrm{Fe}^{\mathrm{III}} \mathrm{CT}$ transitions through $\pi$ overlap between p orbitals of the oxo group and d orbitals on the iron. ${ }^{19}$ In complex $\mathbf{3}$, 
these transitions are superimposed on intraligand transitions of the sulphonato ligand and phenolate to $\mathrm{Fe}^{\mathrm{III}} \mathrm{CT}$ transitions.

\section{Electrochemistry and antioxidant activity of complexes $(1-3)$}

Aqueous solutions of complexes $\mathbf{1}-\mathbf{2}$ display in cyclic voltammetry a single quasi-reversible redox process at -0.18 and $-0.15 \mathrm{~V}$, respectively, attributable to the $\mathrm{Fe}^{\mathrm{III}} / \mathrm{Fe}^{\mathrm{II}}$ couple, which was confirmed by voltammetry at a rotating electrode. These reduction potentials are in accordance with similar values found for the four-coordinate Fe-salen complex. ${ }^{16 \mathrm{~b}}$ At variance, it has been found that for five-coordinate Fe-salen-L (salen = 1,2-bis(salicylidenamino)ethane; $\mathrm{L}=$ anionic ligand) that contain one additional anion bound to $\mathrm{Fe}$, the potentials of the $\mathrm{Fe}^{\mathrm{III}} / \mathrm{Fe}^{\mathrm{II}}$ couples are shifted to much lower values associated with the change in the donor set around Fe. ${ }^{20}$ Therefore,

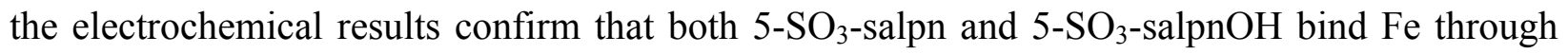
the $\mathrm{N}_{2} \mathrm{O}_{2}$ donor set. The reduction potentials of the Fe complexes are $0.1 \mathrm{~V}$ more negative than the structurally analogue $\mathrm{Mn}$ complexes, $\left[\mathrm{Mn}\left(5-\mathrm{SO}_{3}-\mathrm{Salpn}\right)\right]^{-}$and $\left[\mathrm{Mn}\left(5-\mathrm{SO}_{3}-\mathrm{salpnOH}\right)\right]^{-}{ }^{-}$This $\Delta \mathrm{E}(\mathrm{Fe} / \mathrm{Mn})$ is lower than observed for five- and six-coordinate isoestructural $\mathrm{Fe} / \mathrm{Mn}$ compounds with high proportion of $\mathrm{N}$-donor sites in the coordination sphere, for which $\Delta \mathrm{E}(\mathrm{Fe} / \mathrm{Mn})$ values were found in the 0.25 to $0.55 \mathrm{~V}$ range in $\mathrm{CH}_{3} \mathrm{CN}^{7}$ The low $\Delta \mathrm{E}(\mathrm{Fe} / \mathrm{Mn})$ found for the $\mathrm{Fe} / \mathrm{Mn}$ complexes of 5- $\mathrm{SO}_{3}$-salpn and $5-\mathrm{SO}_{3}-\mathrm{salpnOH}$ is consistent with the fact that $\Delta \mathrm{E}(\mathrm{Fe} / \mathrm{Mn})$ tends to decrease with the increase of the $\mathrm{O} / \mathrm{N}$ ratio in the metal coordination sphere.

In methanol, the cyclic voltammogram of complex 3 showed two quasi-reversible reductions at 0.04 and $-0.35 \mathrm{~V}$ ( vs $\mathrm{Ag} / \mathrm{AgCl}$ ), corresponding to the $\mathrm{Fe}^{\mathrm{III}}{ }_{2} / \mathrm{Fe}^{\mathrm{III}} \mathrm{Fe}^{\mathrm{II}}$ and $\mathrm{Fe}^{\mathrm{III}} \mathrm{Fe}^{\mathrm{II}} / \mathrm{Fe}^{\mathrm{II}}{ }_{2}$ redox couples, which were confirmed by voltammetry at a rotating electrode. The potential of the first one-electron reduction of 3 results to be $0.11 \mathrm{~V}$ more negative than found for the diMn counterpart. ${ }^{12}$ Thus, $\Delta \mathrm{E}(\mathrm{Fe} / \mathrm{Mn})$ is similar as found for mononuclear complexes described above, and indicate that the general trend is still valid for dinuclear $\mathrm{Fe}_{2} / \mathrm{Mn}_{2}$ complexes: "lower potentials for the Fe counterparts and low $\Delta \mathrm{E}(\mathrm{Fe} / \mathrm{Mn})$ for complexes with O-rich coordination sphere". Upon addition of $\mathrm{Et}_{3} \mathrm{~N}$ to the methanol solution of $\mathbf{3}$ the cyclic voltammogram showed an irreversible reduction at $-0.76 \mathrm{~V}$ (vs $\mathrm{Ag} / \mathrm{AgCl}$ ), corresponding to the $\mathrm{Fe}^{\mathrm{III}}{ }_{2} / \mathrm{Fe}^{\mathrm{II}}{ }_{2}$ couple. Linear voltammetry confirmed this process can be assigned to a two-electron reduction. The shift of the $\mathrm{Fe}^{\mathrm{III}}{ }_{2} / \mathrm{Fe}^{\mathrm{II}}{ }_{2}$ couple to lower potentials in basic medium is consistent with the conversion of the starting complex into the $\mu$-oxo-Fe ${ }_{2}$ complex. ${ }^{19}$

\section{SOD activity studies}

The $\mathrm{Fe}^{\mathrm{III}} / \mathrm{Fe}^{\mathrm{II}}$ redox couples of $\mathbf{1}$ and $\mathbf{2}$ are within the potential range $-0.4 \mathrm{~V}\left(\mathrm{O}_{2} / \mathrm{O}_{2}{ }^{\bullet-}\right)$ to $0.65 \mathrm{~V}$ $\left(\mathrm{O}_{2}{ }^{--} / \mathrm{H}_{2} \mathrm{O}_{2}\right)$. Therefore, these complexes are expected to exhibit SOD activity. The activity of complexes 1-2 toward superoxide in aqueous buffer was evaluated by using the nitro blue tetrazolium (NBT) assay. This assay is based on kinetic competition for the superoxide reaction between NBT and the complex with SOD activity. In this way, the SOD activity is inversely related to the amount of formazan, the purple product formed by reaction of NBT with superoxide, observed at $560 \mathrm{~nm}$. Both 1 and $\mathbf{2}$ were found to inhibit the reduction of NBT, as shown in Figure 
5. Inhibition percentages were measured for several complex concentrations and the $I C_{50}$ values were $6.2 \mu \mathrm{M} 1$ and $14 \mu \mathrm{M} \mathrm{2}$. The lower SOD activity of 2 should be the consequence of dimerization of this complex in the basic medium, initiated by deprotonation of the $\mathrm{OH}$ group on $\mathrm{C} 2$ of the propane backbone of the ligand, just as described in the previous section. Dimers are not suitable to mimic SODs, which dismutate $\mathrm{O}_{2}{ }^{-2}$ at an active site containing one metal ion in a $\mathrm{N}_{3} \mathrm{O}_{2}$ environment; and this is especially evident for electronically coupled dimetal centers that are usually involved in catalysis of two-electron redox reactions. In figure 5, the SOD activity of complexes $1-2$ is compared to that of the water soluble $\mathrm{Mn}$ analogues, $\left[\mathrm{Mn}\left(5-\mathrm{SO}_{3}\right.\right.$ salpn $(\mathrm{OH}))]^{-}$. These complexes show $\mathrm{Mn}{ }^{\mathrm{III}} / \mathrm{Mn}^{\mathrm{II}}$ couples at -0.08 and $-0.05 \mathrm{~V}$, and the $I C_{50}$ values, measured under the same experimental conditions as complexes $\mathbf{1} \mathbf{- 2}$, were 0.77 and 1.14 $\mu \mathrm{M}$. These $I C_{50}$ values are one order of magnitude lower than for the $\mathrm{Fe}$ analogues, a fact consistent with the observation that the catalytic rate constants for dismutation of the superoxide anion are related to the metal-centered reduction potential of the catalysts. ${ }^{21}$ Therefore, the more potent mimics are those whose $\mathrm{M}^{\mathrm{III}} / \mathrm{M}^{\mathrm{II}}$ couple are closer to the midpoint potential between the reduction and oxidation of $\mathrm{O}_{2}{ }^{--}\left(\mathrm{E}_{1 / 2} 0.12 \mathrm{~V}\right.$ vs. $\left.\mathrm{Ag} / \mathrm{AgCl}\right)$.

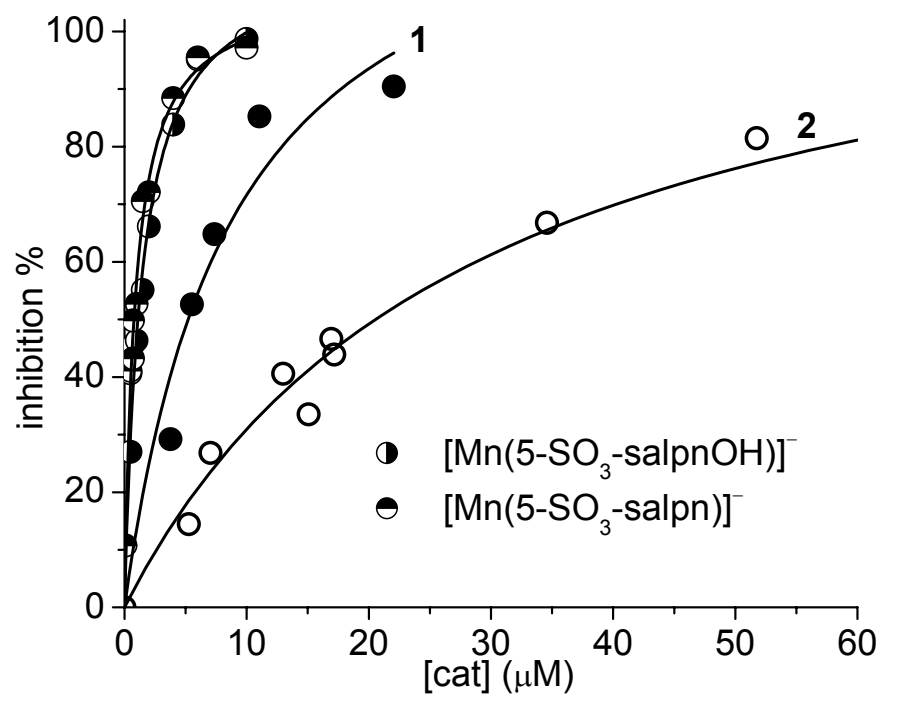

Figure 5. SOD-activity of complexes 1 and 2 and their $\mathrm{Mn}$ analogues in the riboflavinmethionine-NBT assay.

To disproportionate $\mathrm{O}_{2}{ }^{--}$efficiently, the reduction potentials of FeSOD and MnSOD are fine-tuned to -0.02 and $0.05 \mathrm{~V}$, respectively. ${ }^{4}$ These values are much lower than those of the $\mathrm{M}^{3+}{ }_{\text {(ac) }} / \mathrm{M}^{2+}{ }_{\text {(ac) }}$ couples: $\mathrm{Fe}^{3+}{ }_{\text {(ac) }} / \mathrm{Fe}^{2+}{ }_{\text {(ac) }}=0.53 \mathrm{~V}$ and $\mathrm{Mn}^{3+}{ }_{\text {(ac) }} / \mathrm{Mn}^{2+}{ }_{\text {(ac) }}=1.3 \mathrm{~V}$. Despite the metal active sites of FeSOD and MnSOD have been proven to be structurally identical, FeSOD and their MnSOD analogues are inactive when substituted with $\mathrm{Mn}(\mathrm{Fe})$ as a result of the shift in the redox potentials upon substitution. The reduction potential of the Fe substituted MnSOD 
decreases to $-0.48 \mathrm{~V}$, while that of the Mn substituted FeSOD increases to $0.66 \mathrm{~V},{ }^{22}$ and these values are out of the range required for SOD activity. In the case of Fe/Mn-salpn $(\mathrm{OH})$ mimics, $\Delta \mathrm{E}(\mathrm{Fe} / \mathrm{Mn})$ of $0.11 \mathrm{~V}$ reduces $k_{\text {cat }}$ from $2.4-3.6 \times 10^{6} \mathrm{M}^{-1} \mathrm{~s}^{-1}$ for the Mn complexes to $1.96-4.4$ $\times 10^{5} \mathrm{M}^{-1} \mathrm{~s}^{-1}$ for the $\mathrm{Fe}$ analogues. For the active site of $\mathrm{SOD}$, which contains a $\mathrm{N}_{3} \mathrm{O}_{2}$ donor set, the expected $\Delta \mathrm{E}(\mathrm{Fe} / \mathrm{Mn})$ based on first sphere effects only, should be between $0.11\left(\mathrm{~N}_{2} \mathrm{O}_{2}\right.$, present study) and $0.45 \mathrm{~V}\left(\mathrm{~N}_{4} \mathrm{O}_{2}{ }^{7 \mathrm{~b}}\right)$. These facts support the idea that primary ligand sphere in $\mathrm{Fe}$ and MnSODs should render both metal ions competent to carry out the enzymatic reaction and that it is the more distant electrostatic contributions that may be the source of metal-specific activity. $^{7 \mathrm{a}}$

\section{CAT activity studies}

Catalase enzymes disproportionate hydrogen peroxide by converting it into water and oxygen. While FeCATs are heme-proteins that dismutate $\mathrm{H}_{2} \mathrm{O}_{2}$ employing $\mathrm{Fe}^{\mathrm{III}} / \mathrm{Fe}^{\mathrm{IV}}=\mathrm{O}^{\bullet+}$, MnCATs possess a $\mathrm{Mn}_{2}\left(\mu-\mathrm{O}_{2} \mathrm{CR}\right)(\mu-\mathrm{O} / \mathrm{OH})_{2}$ structural unit as the active site that cycles between the $\mathrm{Mn}^{\mathrm{II}}{ }_{2}$ and $\mathrm{Mn}_{2}{ }_{2}$ oxidation states during catalysis. ${ }^{2}$ To act as CAT mimics, synthetic catalysts must have metal centered redox couples within the $0.04 \mathrm{~V}\left(\mathrm{O}_{2} / \mathrm{H}_{2} \mathrm{O}_{2}\right)$ to $1.01 \mathrm{~V}\left(\mathrm{H}_{2} \mathrm{O} / \mathrm{H}_{2} \mathrm{O}_{2}\right)$ potential range. A number of dinuclear manganese-based complexes has been investigated as low molecular weight catalytic scavengers of $\mathrm{H}_{2} \mathrm{O}_{2}{ }^{5 \mathrm{~b}-\mathrm{d}}$ Among them, the complex $\left[\mathrm{Mn}_{2}\left(5-\mathrm{SO}_{3}\right.\right.$ salpentO)( $\mu$-OAc) $(\mathrm{OMe})]^{-}$has shown to be highly efficient to dismutate $\mathrm{H}_{2} \mathrm{O}_{2}$ in basic aqueous solution, where the complex converts into $\left[\mathrm{Mn}_{2}\left(5-\mathrm{SO}_{3} \text {-salpentO }\right)(\mu-\mathrm{O})\right]^{-12}{ }^{12} \mathrm{Fe}_{2}\left(\mu-\mathrm{O}_{2} \mathrm{CR}\right)_{1(2)}(\mu-$ $\mathrm{O}(\mathrm{R})$ ) centers are ubiquitous in biology, occurring in oxygen transport proteins, ribonucleotide reductases, purple acid phosphatases, methane monooxygenase, among others, but are not involved in CAT activity. ${ }^{23}$ To extend the analysis of the effect of the ligand on redox properties and activity of $\mathrm{Fe} / \mathrm{Mn}$ analogues to dinuclear complexes, we decided to evaluate the CAT activity of 3 , and compare it to that of $\left[\mathrm{Mn}_{2}\left(5-\mathrm{SO}_{3} \text {-salpentO) }(\mu-\mathrm{OAc})(\mu-\mathrm{OMe})\right]^{-}\right.$and $\left[\mathrm{Mn}_{2}(5-\right.$ $\mathrm{SO}_{3}$-salpentO)( $\left.\left.\mu-\mathrm{O}\right)\right]^{-}$.

To disproportionate $\mathrm{H}_{2} \mathrm{O}_{2}$, the catalyst must be reduced and oxidized by two-electrons in each half-reaction. The estimated two-electron reduction potential for the $\mathrm{Fe}^{\mathrm{III}}{ }_{2} / \mathrm{Fe}^{\mathrm{II}}{ }_{2}$ couple of $\mathbf{3}$ $(-0.19 \mathrm{~V})$ is out of the range required for CAT activity, and, thus, it is expected to be active through a catalytic cycle involving iron in higher oxidation state. The activity of complex $\mathbf{3}$, and its $\mathrm{Mn}_{2}$ analogue, toward $\mathrm{H}_{2} \mathrm{O}_{2}$ in aqueous solution was determined by volumetric measurement of evolved $\mathrm{O}_{2}$. Figure 6(a) shows the evolution of $\mathrm{O}_{2}$ vs. time after addition of 150 equivalents of $\mathrm{H}_{2} \mathrm{O}_{2}$ to aqueous solutions containing $3.3 \mathrm{mmol}$ of 3 or $\left[\mathrm{Mn}_{2}\left(5-\mathrm{SO}_{3}\right.\right.$-salpentO $)(\mu-\mathrm{OAc})(\mu-$ $\mathrm{OMe})]^{-}$. It can be seen that the diMn complex dismutates all $\mathrm{H}_{2} \mathrm{O}_{2}$ within $1 \mathrm{~h}$, whereas the $\mathrm{Fe}_{2}$ analogue requires $7.3 \mathrm{~h}$ to dismutate the same $\mathrm{H}_{2} \mathrm{O}_{2}$ amount. The CAT activity of the $\mathrm{Fe}_{2} / \mathrm{Mn}_{2}$ analogues was also evaluated in basic medium. After addition of $\mathrm{Et}_{3} \mathrm{~N}$ to the complex solution, the starting complexes convert into $\left[\mathrm{M}_{2}\left(5-\mathrm{SO}_{3} \text {-salpentO }\right)(\mu-\mathrm{O})\right]^{-}$. As it was described in the previous section, the reduction potential of the $\mu$-oxo- $\mathrm{M}_{2}{ }^{\mathrm{III}}$ centers shifts to potentials considerably lower than those of $\mu-\mathrm{OR}(\mathrm{OH})-\mathrm{M}_{2}{ }^{\mathrm{III}}$ centers, so the catalytic disproportionation of $\mathrm{H}_{2} \mathrm{O}_{2}$ in basic medium must certainly involve higher metal oxidation states. As shown in figure 
6(b), under the same experimental conditions, the $\mu$-oxo- $\mathrm{Mn}_{2}{ }^{\mathrm{III}}$ complex dismutates 150 eq $\mathrm{H}_{2} \mathrm{O}_{2}$ in $4 \mathrm{~min}$, while the $\mu$-oxo- $\mathrm{Fe}_{2}{ }^{\mathrm{III}}$ analogue takes more than $7 \mathrm{~h}$. Thus, in aqueous solution, 3 is about 10 times slower than the $\mathrm{Mn}_{2}{ }^{\mathrm{III}}$ analogue, while the $\mu$-oxo- $\mathrm{Fe}_{2}{ }^{\mathrm{III}}$ complex is about 100 times slower than its $\mu$-oxo- $\mathrm{Mn}_{2}{ }^{\text {III }}$ counterpart in basic medium.

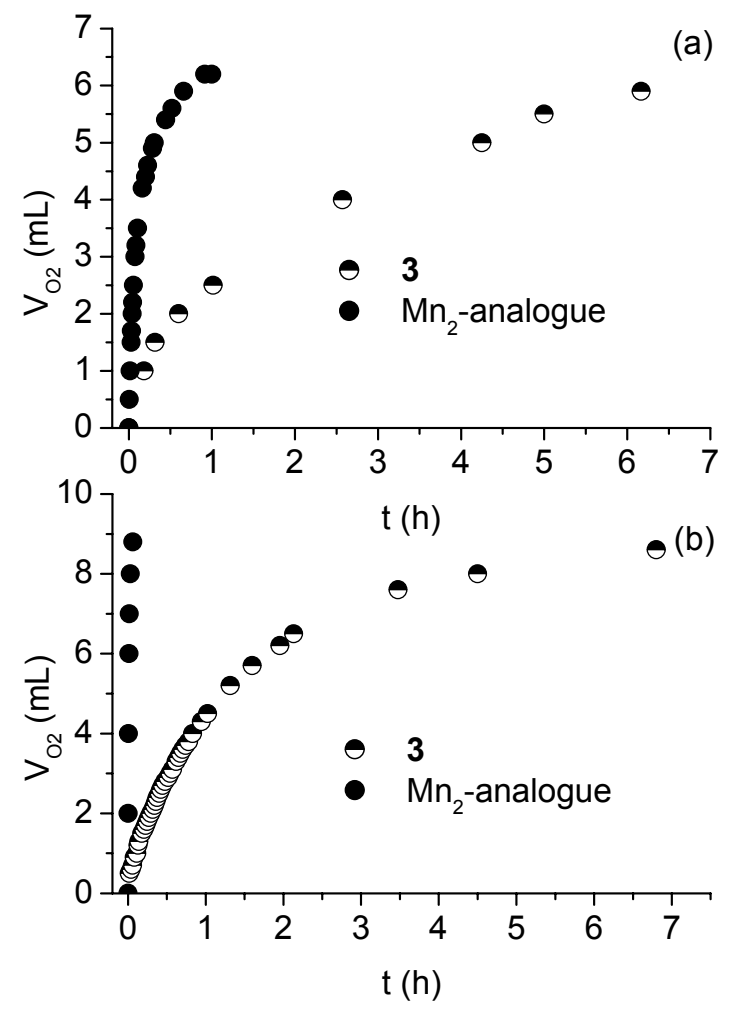

Figure 6. Volume of $\mathrm{O}_{2}$ evolved from a mixture of (a) catalyst $(1.1 \mathrm{mM})+150$ eq $\mathrm{H}_{2} \mathrm{O}_{2}$ in 3.05 $\mathrm{mL} \mathrm{H}_{2} \mathrm{O}$. (b) catalyst $(1.56 \mathrm{mM})+150$ eq $\mathrm{H}_{2} \mathrm{O}_{2}+10$ eq $\mathrm{Et}_{3} \mathrm{~N}$ in $3.07 \mathrm{~mL} \mathrm{H}_{2} \mathrm{O} . \mathrm{T}=298 \mathrm{~K}$.

It is known that dimanganese complexes of the $\mathrm{X}$-salpentOH family disproportionate $\mathrm{H}_{2} \mathrm{O}_{2}$ employing the $\mathrm{Mn}_{2}{ }^{\mathrm{III}} /\left(\mathrm{Mn}^{\mathrm{IV}}=\mathrm{O}\right)_{2}$ couple. ${ }^{24}$ In order to obtain additional information on the $\mathrm{Fe}$ species involved in the $\mathrm{H}_{2} \mathrm{O}_{2}$ disproportionation in basic medium, a mixture of $\mathbf{3}+150$ eq $\mathrm{H}_{2} \mathrm{O}_{2}$ +10 eq $\mathrm{Bu}_{4} \mathrm{NOH}$ in DMF was monitored by resonance Raman (RR) spectroscopy. DMF was used because water or methanol did not show enhanced lines in the RR spectra. The RR spectra, obtained with $514 \mathrm{~nm}$ excitation, are shown in figure 7(a). In the spectrum of complex 3 in DMF the peak observed at $729 \mathrm{~cm}^{-1}$ may be assigned to a PhO-Fe stretching mode. ${ }^{166,25} \mathrm{RR}$ spectra recorded at different times during the reaction show two additional peaks at 513 and $613 \mathrm{~cm}^{-1}$. The peak at $513 \mathrm{~cm}^{-1}$ may be tentatively assigned to the $v_{\mathrm{s}}(\mathrm{Fe}-\mathrm{O}-\mathrm{Fe})$ mode, whose intensity appears to be related to the presence of additional bridging groups as well as to the nature of the non bridging ligands. ${ }^{14}$ In particular, the intensity of this mode is depressed by phenolate ligands, 
and this could be the reason for its low intensity in the present case. Therefore, RR spectroscopy seems to confirm that the $\mu$-oxo- $\mathrm{Fe}_{2}{ }^{\mathrm{III}}$ species could be involved in the catalytic cycle. The spectrophotometric monitoring of the reaction of the $\mu$-oxo- $\mathrm{Fe}_{2}{ }^{\mathrm{III}}$ shows that the absorption band at $368 \mathrm{~nm}$ decreases with time during the reaction course (figure 7(b)). This indicates that, besides the intrinsic properties of the $\mathrm{Mn} / \mathrm{Fe}$ complexes that determine their different activity toward $\mathrm{H}_{2} \mathrm{O}_{2}$, the lower activity of the $\mathrm{Fe}_{2}$-catalyst is in part due to partial decomposition of the complex during the $\mathrm{H}_{2} \mathrm{O}_{2}$ disproportionation. In line with this, the peak at $614 \mathrm{~cm}^{-1}$ in the $\mathrm{RR}$ spectra of the reaction mixture may be assigned to the enhanced $v_{\text {phO-Fe }}$ mode of a mononuclear species formed by decomposition of the catalyst.
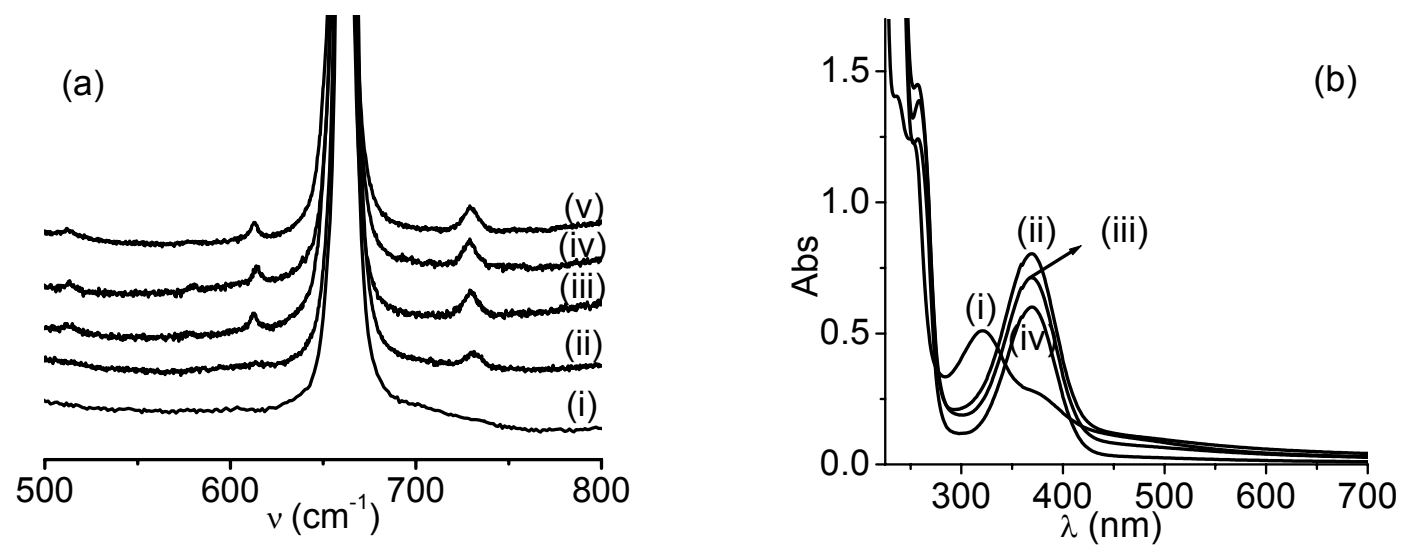

Figure 7. (a) RR spectra of solvent alone (i); a DMF solution of $\mathbf{3}$ (ii); a mixture of $\mathbf{3}+150$ eq $\mathrm{H}_{2} \mathrm{O}_{2}+10$ eq $\mathrm{Bu}_{4} \mathrm{NOH}$ at 14 (iii), 17 (iv) and $35 \mathrm{~min}$ (v) after mixing. $514 \mathrm{~nm}$ excitation; [3] = $1.8 \mathrm{mM}$. (b) UV-vis spectra of 3 (i) and a reaction mixure of $3\left(5.55 \times 10^{-2} \mathrm{mM}\right)+150 \mathrm{eq}_{2} \mathrm{O}_{2}+$ 5 eq $\mathrm{Et}_{3} \mathrm{~N}, 3 \mathrm{~min}$ (ii), $2 \mathrm{~h}$ (iii) and $6 \mathrm{~h}$ (iv) after mixing.

\section{Conclusions}

The present results show that the length of the aliphatic chain in 5- $\mathrm{SO}_{3}-\mathrm{salpn}, 5-\mathrm{SO}_{3}-\mathrm{salpnOH}$ and 5- $\mathrm{SO}_{3}$-salpentOH controls the nuclearity of the iron complex affording compounds that are structurally analogous to those of $\mathrm{Mn}$. 5- $\mathrm{SO}_{3}$-salpn and 5- $\mathrm{SO}_{3}-\mathrm{salpnOH}$ modulate the ironcentered reduction potential to values that are only $0.1 \mathrm{~V}$ more negative than those of their $\mathrm{Mn}$ counterparts and result in $\mathrm{Fe} / \mathrm{Mn}$ complexes that are thermodynamically competent to disproportionate $\mathrm{O}_{2}{ }^{\bullet-}$. Therefore, $1-2$ and their $\mathrm{Mn}$ analogues behave as cambialistic SOD models. However, the more distant $\mathrm{Fe}^{\mathrm{III}} / \mathrm{Fe}^{\mathrm{II}}$ couple to the midpoint potential for $\mathrm{O}_{2}{ }^{\bullet-}$ dismutation and the lower stability of the Fe complexes toward dissociation render complexes 1 - 2 less efficient than the $\mathrm{Mn}$ counterpart. 5- $\mathrm{SO}_{3}$-salpentOH affords $\mathrm{Fe}_{2} / \mathrm{Mn}_{2}$ analogues that convert into $\mu$-oxo- $\mathrm{M}_{2}$ species and are both competent to disproportionate $\mathrm{H}_{2} \mathrm{O}_{2}$. However, 
partial decomposition of complex 3 results in a catalyst poorer than the $\mathrm{Mn}_{2}$ counterpart. This is especially evident in basic medium where the $\mathrm{Mn}_{2}$ catalyst shows enhanced activity and stability.

\section{Experimental Section}

General. All reagents or analytical grade chemicals were used as purchased. Solvents were purified by standard methods. The concentration of $\mathrm{H}_{2} \mathrm{O}_{2}$ stock solution was determined by iodometric titration. Disodium salts of 1,5-bis(5-sulphonatosalicylidenamino)pentan-3-ol (5- $\mathrm{SO}_{3}$ salpentOH), 1,3-bis(5-sulphonatosalicylidenamino)propan-2-ol (5- $\mathrm{SO}_{3}$-salpnOH) and 1,3-bis(5sulphonatesalicylidenamino)propane (5- $\mathrm{SO}_{3}$ - $\mathrm{Salpn}$ ) were prepared by Schiff base condensation of sodium salicylaldehyde-5-sulphonate ${ }^{26}$ and 1,5-diaminopentan-3-ol, 1,3-diaminopropan-2-ol and 1,3-diaminopropane, respectively, as previously reported. ${ }^{9,12}$

\section{Physical measurements}

Electronic spectra were recorded on a JASCO V550 spectrophotometer with thermostated cell compartments. IR spectra were recorded on a Perkin-Elmer Spectrum One FT-IR spectrophotometer. ESI-mass spectra were recorded on a Perkin-Elmer SCIEX 365 LCMSMS mass spectrometer. The electrospray solutions were prepared in methanol with final $\approx 10^{-5} \mathrm{M}$ concentration and the flow rate was $5 \mu \mathrm{L} \mathrm{min}{ }^{-1}$. ${ }^{1} \mathrm{H}$ spectra were recorded on a Bruker AC 200 NMR spectrometer at ambient probe temperature (ca $26{ }^{\circ} \mathrm{C}$ ), with nominal operating frequency of 200.1 MHz. The electrochemical experiments were performed with a computer-controlled Princeton Applied Research potentiostat, model VERSASTAT II, with model 270/250 Research Electrochemistry Software. Studies were carried out under Ar, in water or methanol solutions using $0.1 \mathrm{M} \mathrm{KNO}_{3}$ or $\mathrm{Bu}_{4} \mathrm{NPF}_{6}$, respectively, as supporting electrolyte and $\sim 10^{-3} \mathrm{M}$ of the complex. The working electrode was a $\mathrm{Pt}$ wire and the reference electrode was $\mathrm{Ag} / \mathrm{AgCl}$ with $\mathrm{Pt}$ as the auxiliary electrode. Resonance Raman spectra were measured in backscattering geometry by using a confocal microscope (Olympus BX41) coupled to a single-stage spectrograph (Jobin Yvon XY 800) equipped with a liquid-nitrogen-cooled back-illuminated CCD detector and an 1800 1/mm grating. Elastic scattering was rejected with an edge filter (Semrock). The $514 \mathrm{~nm}$ line of a cw argon laser (Coherent Innova 70c) was focused into ca. 100 microL solution film in a rotating quartz cell using a $20 x$ objective $(20.5 \mathrm{~mm}$ wd, 0.35 N.A.) Spectra were acquired with laser powers of about $13 \mathrm{~mW}$ at sample, and were processed with home-made software for baseline correction and peak determination. Spectral positions were aligned towards standard $\mathrm{Hg}$ and Na lamps.

\section{Synthesis of complexes}

$\mathbf{N a}_{2}\left[\mathbf{F e}\left(5-\mathbf{S O}_{3} \text {-salpn)( } \mathbf{H}_{2} \mathbf{O}\right)_{2}\right] \mathbf{O H} \cdot 4 \mathbf{H}_{2} \mathrm{O}\left(\mathbf{1} \cdot 4 \mathrm{H}_{2} \mathrm{O}\right) \cdot \mathrm{FeCl}_{3} \cdot 6 \mathrm{H}_{2} \mathrm{O}(110 \mathrm{mg}, 0.4 \mathrm{mmol})$ was added to a solution of $\mathrm{Na}_{2}$ [5-SO $\mathrm{SO}_{3}$-salpn] $(193 \mathrm{mg}, 0.43 \mathrm{mmol})$ in methanol $(10 \mathrm{~mL})$ and left to stir for $12 \mathrm{~h}$. After addition of $2 \mathrm{~mL}$ of $\mathrm{CH}_{3} \mathrm{CN}$, the complex precipitated as a red-wine solid that was 
filtered off, washed with ether and dried under vacuum. Yield: $110 \mathrm{mg}(0.17 \mathrm{mmoles}, 42 \%)$. Anal. calcd. for $\mathrm{C}_{17} \mathrm{H}_{19} \mathrm{FeN}_{2} \mathrm{Na}_{2} \mathrm{O}_{11} \mathrm{~S}_{2} \cdot 4 \mathrm{H}_{2} \mathrm{O}$ : C 30.7, $\mathrm{H}$ 4.09, $\mathrm{N}$ 4.21, Na 6.9\%; found: $\mathrm{C} 31.02, \mathrm{H}$ 3.60, N 4.25, Na 6.5\%. Significant IR bands (KBr, $\left.v \mathrm{~cm}^{-1}\right)$ : $v_{\mathrm{OH}} 3427$ (broad), $v_{\mathrm{CH}} 3045, v_{\mathrm{C}=\mathrm{N}}$ 1623, $v_{\text {phO }} 1545, v_{\mathrm{SO} 3} 1113 / 1028$. UV-vis $\lambda_{\max } \mathrm{nm}\left(\varepsilon \mathrm{M}^{-1} \mathrm{~cm}^{-1}\right)$ in $\mathrm{H}_{2} \mathrm{O}: 316$ (5950), 513 (2270).

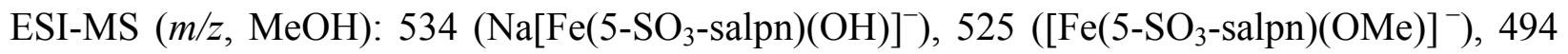
([Fe(5-SO ${ }_{3}$-salpn) $\left.]^{-}\right)$.

$\mathbf{N a}_{2}\left[\mathbf{F e}\left(5-\mathbf{S O}_{3}\right.\right.$-salpnOH$\left.)\left(\mathbf{H}_{2} \mathbf{O}\right)_{2}\right] \mathbf{C l} \cdot \mathbf{7} \mathbf{H}_{2} \mathbf{O}\left(\mathbf{2} \cdot 7 \mathrm{H}_{2} \mathrm{O}\right) \cdot \mathrm{Na}_{2}\left[5-\mathrm{SO}_{3}\right.$-salpnOH] $(191 \mathrm{mg}, 0.38 \mathrm{mmol})$ and $\mathrm{FeCl}_{3} \cdot 6 \mathrm{H}_{2} \mathrm{O}(110 \mathrm{mg}, 0.4 \mathrm{mmol})$ were mixed in methanol $(11 \mathrm{~mL})$. The mixture was stirred for $12 \mathrm{~h}$ and a red-wine powder precipitated after slow evaporation of the solvent. The solid was collected by filtration, washed with ether and dried under vacuum. Yield: $101 \mathrm{mg}(0.13 \mathrm{mmol}$, 34 \%). Anal. Calcd. for $\mathrm{C}_{17} \mathrm{ClH}_{18} \mathrm{FeN}_{2} \mathrm{Na}_{2} \mathrm{O}_{11} \mathrm{~S}_{2} \cdot 7 \mathrm{H}_{2} \mathrm{O}$ : C 27.09, H 4.28, $\mathrm{N} 3.72, \mathrm{Na} 6.1 \%$; found: $\mathrm{C} 26.95, \mathrm{H} 4.05, \mathrm{~N} 3.67, \mathrm{Na} 6.2 \%$. Conductimetric titration of 2 with $\mathrm{AgNO}_{3}$ afforded 1 eq. of $\mathrm{Cl}^{-}$per mol of complex. Significant IR bands $\left(\mathrm{KBr}, v \mathrm{~cm}^{-1}\right)$ : $v_{\mathrm{OH}} 3405$ (broad), $v_{\mathrm{CH}} 3091, v_{\mathrm{C}=\mathrm{N}}$ 1630, $v_{\text {phO }} 1538, v_{\mathrm{SO} 3} 1106 / 1028$. UV-vis $\lambda_{\max } \mathrm{nm}\left(\varepsilon \mathrm{M}^{-1} \mathrm{~cm}^{-1}\right) \mathrm{H}_{2} \mathrm{O}: 310$ (11175), 474 (2590). ESI-MS $(m / z, \mathrm{MeOH}): 585.7\left(\mathrm{NaH}\left[\mathrm{Fe}\left(5-\mathrm{SO}_{3}-\mathrm{salpnOH}\right)(\mathrm{MeOH})\left(\mathrm{H}_{2} \mathrm{O}\right)\right]^{+}\right), 563.7\left(\mathrm{H}_{2}\left[\mathrm{Fe}\left(5-\mathrm{SO}_{3}{ }^{-}\right.\right.\right.$ salpnOH $\left.\left.\left(\mathrm{H}_{2} \mathrm{O}\right)(\mathrm{MeOH})\right]^{+}\right)$.

$\mathrm{Na}_{2}\left[\mathrm{Fe}_{2}\left(5-\mathrm{SO}_{3}\right.\right.$-salpentO) $\left.(\mu-\mathrm{OAc})(\mu-\mathrm{OH})\left(\mathrm{H}_{2} \mathrm{O}\right)_{2}\right] \mathbf{O H} \cdot 3 \mathrm{H}_{2} \mathrm{O}\left(3 \cdot 3 \mathrm{H}_{2} \mathrm{O}\right)$. A solution of $\mathrm{Fe}(\mathrm{OAc})_{2}$ (296 mg, $1.70 \mathrm{mmol}$ ) in $3 \mathrm{~mL}$ of methanol was added to a solution of $\mathrm{Na}_{2}$ [5-SO $-\mathrm{SO}_{3}$-salpentOH] (500 mg, $0.94 \mathrm{mmol})$ in methanol $(3 \mathrm{~mL})$. The mixture was stirred for $24 \mathrm{~h}$ and a solid began to form slowly. After standing for 4 days, the resulting brick-red precipitate was collected by filtration, washed with cold methanol and dried under vacuum. Yield: $420 \mathrm{mg}(0.51 \mathrm{mmol}$, 54\%). Anal. Calcd. for $\mathrm{C}_{21} \mathrm{H}_{26} \mathrm{Fe}_{2} \mathrm{~N}_{2} \mathrm{Na}_{2} \mathrm{O}_{15} \mathrm{~S}_{2} \cdot 3 \mathrm{H}_{2} \mathrm{O}$ : C 30.7, H 3.92, N 3.41, Fe 13.6, Na 5.6\%; found: C 30.6, H 3.60, N 4.18, Fe 12.9, Na 6.1\%. Significant IR bands $\left(\mathrm{KBr}, v \mathrm{~cm}^{-1}\right): v_{\mathrm{OH}} 3430$ (broad), $v_{\mathrm{CH}} 2820,2860,2920,2960, v_{\mathrm{C}=\mathrm{N}} 1635, v_{\mathrm{Ph}-\mathrm{O}} 1537, v_{\mathrm{OAc}} 1427 / 1552, v_{\mathrm{SO} 3} 1112 / 1039$. UV-vis $\lambda_{\max } \mathrm{nm}\left(\varepsilon \mathrm{M}^{-1} \mathrm{~cm}^{-1}\right) \mathrm{H}_{2} \mathrm{O}: 220$ (57300), 320 (9270), 368 (sh, 5240), 440 (broad, 2180). ESI-MS $\quad(m / z, \quad \mathrm{MeOH}): 683 \quad\left(\left[\mathrm{Fe}_{2}\left(5-\mathrm{SO}_{3} \text {-salpentO)(MeO)(OAc) }\right]^{-}\right), \quad 737 \quad\left(\mathrm{Na}_{2}\left[\mathrm{Fe}_{2}\left(5-\mathrm{SO}_{3}-\right.\right.\right.\right.$ salpentO $\left.\left.)(\mathrm{MeO})_{2}(\mathrm{OAc})\right]^{-}\right)$and $765\left(\mathrm{Na}\left[\mathrm{Fe}_{2}\left(5-\mathrm{SO}_{3} \text {-salpentO }\right)(\mathrm{MeO})(\mathrm{OAc})_{2}\right]^{-}\right)$.

\section{Indirect SOD assay}

The SOD activity of the complexes was assayed by measuring inhibition of the photoreduction of nitro blue tetrazolium (NBT), by a method slightly modified from that originally described by Beauchamps and Fridovich. ${ }^{27}$ The solutions containing riboflavin $\left(3.4 \times 10^{-6} \mathrm{M}\right)$, methionine $(0.01 \mathrm{M})$, NBT $\left(4.6 \times 10^{-5} \mathrm{M}\right)$ and complex of various concentrations were prepared with phosphate buffer ( $\mathrm{pH}$ 7.8). The mixtures were illuminated by a regular compact fluorescent lamp with a constant light intensity at $25^{\circ} \mathrm{C}$. The reduction of NBT was monitored at $560 \mathrm{~nm}$ with various illumination periods ( $t$ ). Rates in the absence and in the presence of different concentrations of complex were determined and plotted vs. complex concentration. Inhibition percentage was calculated according to: $\left\{(\Delta \mathrm{Abs} / t)_{\text {without complex }}-(\Delta \mathrm{Abs} / t)_{\text {with complex }}\right\} \times 100 /$ $(\Delta \mathrm{Abs} / t)_{\text {without complex. }}$ The $I C_{50}$ value represents the concentration of the SOD mimic that induces a $50 \%$ inhibition of the reduction of NBT. Control experiments were performed on mixtures of 
NBT + complex, riboflavin + complex, and NBT + methionine + complex, in phosphate buffer, to ensure that the complex does not react independently with any of the components of the mixture. On the basis of competition with NBT, at 50\% inhibition the rates of the reactions of NBT and the mimic with $\mathrm{O}_{2}{ }^{--}$are equal, $k_{\text {cat }}$ [catalyst] $=k_{\mathrm{NBT}}[\mathrm{NBT}]$, where $k_{\mathrm{NBT}}(\mathrm{pH}=7.8)=5.94 \times$ $10^{4} \mathrm{M}^{-1} \mathrm{~s}^{-1}{ }^{28}$ Hence, the catalytic rate constant was calculated as $k_{\mathrm{cat}}=k_{\mathrm{NBT}}[\mathrm{NBT}] / I C_{50}$.

\section{Disproportionation of $\mathrm{H}_{2} \mathrm{O}_{2}$}

The $\mathrm{H}_{2} \mathrm{O}_{2}$ disproportionation catalyzed by 1-3 was measured by volumetric determination of the evolved $\mathrm{O}_{2}$ from reaction mixtures in water. A round-bottom flask with a stopcock equipped gas delivery side tube connected to a gas-measuring burette (precision of $0.1 \mathrm{~mL}$ ) was used. A closed vessel containing a solution of catalyst in water or $\mathrm{Et}_{3} \mathrm{~N}$ ([Et $\left.\mathrm{Et}_{3} \mathrm{~N}\right]$ : [catalyst] ratios from 5:1 to 20:1) was stirred at constant temperature on a water bath. Previously thermostated $\mathrm{H}_{2} \mathrm{O}_{2}$ $\left(\left[\mathrm{H}_{2} \mathrm{O}_{2}\right]\right.$ :[catalyst] ratio 150:1) was injected through a silicon stopper, and the evolved dioxygen was volumetrically measured.

\section{Acknowledgements}

We thank the National University of Rosario, CONICET and the National Agency for Sciences Promotion for financial support. We thank M. Micheloud, M. De Gaudio, L. Ghinamo and E. Bianchi for activity measurements.

\section{References}

1 (a) Chang, L.; Slot, J. W.; Geuze, H. P.; Crapo J. D. J. Cell Biol. 1988, 107, 2169. (b) Barondeau, D. P.; Kassmann, C. J.; Bruns, C. K.; Tainer, J. A.; Getzoff, E. D. Biochemistry 2004, 43, 8038. (c) Edwards, R. A.; Baker, H. M.; Whittaker, M. M.; Whittaker, J. W.; Jameson, G. B.; Baker, E. N. J. Biol. Inorg. Chem. 1998, 3, 161. (d) Noodleman, L.; Lovell, T.; Han, W. G.; Li, J.; Himo, F. Chem. Rev. 2004, 104, 459.

2 (a) Bravo, J.; Mate, M. J.; Schneider, T.; Switala, J.; Wilson, K.; Loewen, P. C.; Fita, L. Proteins Struct. Funct. Bioinf. 1999, 34, 155. (b) Antonyuk, S. V.; Barynin, V. V. Crystallogr. Reports 2000, 45, 105. (c) Barynin, V. V.; Whittaker, M. M.; Antonyuk, S. V.; Lamzin, V. S.; Harrison, P. M.; Artymiuk, P. J.; Whittaker, J. W. Structure 2001, 9, 725.

3 (a) Ihara, Y.; Chuda, M.; Kuroda, S.; Hayabara, T. J. Neurol. Sci. 1999, 170, 90. (b) Toh, Y.; Kuninaka, S.; Mori, M.; Oshiro, T.; Ikeda, Y.; Nakashima, H.; Baba, H.; Kohnoe, S.; Okamura, T.; Sugimachi, K. Oncology 2000, 59, 223.

4 Miller, A. F. In Handbook of Metalloproteins; Messerschmidt, A.; Huber, R.; Wieghardt, K.; Paulos T. Eds.; Wiley and Sons: Chichester, U.K., 2001; Vol. 2, pp 668-682. 
5 (a) Mukhopadhyay,S.; Mandal, S. K.; Bhaduri, S.; Armstrong, W. H. Chem. Rev. 2004, 104, 3981. (b) Wu, A. J.; Penner-Hahn, J. E.; Pecoraro, V. L. Chem. Rev. 2004, 104, 903-938. (c) Signorella, S.; Rompel, A.; Buldt-Karentzopoulos, K.; Krebs, B.; Pecoraro, V. L.; Tuchagues, J.-P.; Inorg. Chem. 2007, 46, 10864-10868. (d) Signorella, S.; Tuchagues, J.-P.; Moreno, D.; Palopoli, C. In Inorganic Biochemistry Research Progress; Hughes, J. G.; Robinson, A. J. Eds.; Nova Sci. Publ. Inc.: New York, 2008; pp 243.

6 (a) Riley, D. P. Chem. Rev. 1999, 99, 2573. (b) Lahaye, D.; Muthukumaran, K.; Hung, C. H.; Gryko, D.; Rebouças, J. S.; Spasojevic, I.; Batinic-Haberle, I.; Lindsey, J. S. Biorg. Med. Chem. 2007, 15, 7066. (c) Spasojevic, I.; Batinic-Haberle, I.; Stevens, R. D.; Hambright, P.; Thorpe, A. N.; Grodkowski, J.; Neta, P.; Fridovich, I. Inorg. Chem. 2001, 40, 726.

7 (a) Sjödin, M.; Gätjens, J.; Tabares, L. C.; Thuéry, P.; Pecoraro, V. L.; Un, S. Inorg. Chem. 2008, 47, 2897. (b) Groni, S.; Hureau, C.; Guillot, R.; Blondin, G.; Blain, G.; AnxolabéhèreMallart, E. Inorg. Chem. 2008, 47,11783, and refs. cited therein.

8 Doctrow, S. R.; Huffman, K.; Marcus, C. B.; Tocco, C.; Malfroy, E.; Adinolfi, C. A.; Kruk, H.; Baker, K.; Lazarowych, N.; Mascarenhas, J.; Malfroy, B. J. Med. Chem. 2002, 45, 4549.

9 Moreno, D.; Daier, V.; Palopoli, C.; Tuchagues, J. P.; Signorella S. J. Inorg. Biochem. 2010, 104, 496.

10 (a) Deacon, G. B.; Phillips, R. J. Coord. Chem. Rev. 1980, 33, 227. (b) Nakamoto, K. Infrared and Raman Spectra of Inorganic and Coordination Compounds, $5^{\text {th }}$ Edn.; WileyInterscience: New York, 1997; Part B, p 60.

11 Signorella, S.; Palopoli, C.; Daier, V.; Ghinamo, L.; Micheloud M. EUROBIC10, Thesaloniki, Greece, October 22-26, 2010: Abstract No 233.

12 Palopoli, C.; Bruzzo, N.; Ghinamo, L.; De Gaudio, M.; Beltramino, C.; Signorella, S. EUROBIC10, Thesaloniki, Greece, October 22-26, 2010: Abstract No 183.

13 (a) Ramesh, K.; Mukherjee, R. J. Chem. Soc., Dalton Trans. 1992, 83. (b) Cook, D.; Cummins, D.; McKenzie, E.D. J. Chem. Soc., Dalton Trans. 1976, 1369.

14 Sanders-Loehr, J.; Wheeler, W. D.; Shiemke, A. K.; Averill, B. A.; Loehr, T. M. J. Am. Chem. Soc. 1989, 111,8084.

15 LaMar G. N. In NMR of Paramagnetic Molecules, Principles and Applications; LaMar, G. N.; Worrocks, W. D.; Holm, R. H. Eds.; Academic Press: New York, 1973, ch 3.

16 (a) LaMar, G. N.; Eaton, G. R.; Holm, R. H.; Walker, F. A. J. Am. Chem. Soc. 1973, 95, 63. (b) Pyrz, J. W.; Roe, A. L.; Stern, L. J.; Que, Jr., L. J. Am. Chem. Soc. 1985, 107, 614.

17 Gelasco, A.; Kirk, M. L.; Kampf, J. W.; Pecoraro, V. L. Inorg. Chem., 1997, 36, 1829.

18 Aimscough, E. W.; Brodie, A. M.; Plowman, J. E.; Brown, K. L.; Addison, A. W.; Gainsford, A. R. Inorg. Chem. 1980, 19, 3655.

19 Armstrong, W. H.; Spool, A.; Papaefthymiou, G. C.; Frankel, R. B.; Lippard, S. J J. Am. Chem. Soc. 1984, 106, 3653.

20 Mukherjee, R. N.; Abrahamson, A. J.; Patterson, G. S.; Stack, T. D. P.; Holm, R. H. Inorg. Chem. 1988, 27, 2137. 
21 Batinic-Haberle, I.; Spasojevic, I.; Hambright, P.; Benov, L.; Crumbliss, A. L.; Fridovich, I. Inorg. Chem. 1999, 38, 4011.

22 Vance, C. K.; Miller, A. F.; J. Am. Chem. Soc. 1998, 120, 461.

23 Stassinopoulos, A.; Mukerjee, S.; Caradonna, J. P. In Mechanistic Bioinorganic Chemistry; Thorp, H. H.; Pecoraro, V. L. Eds; Advances in Chemistry Series, 246; ACS: Washington DC, 1995; pp 83-120.

24 (a) Moreno, D.; Palopoli, C.; Daier, V.; Shova, S.; Vendier, L.; González Sierra, M.; Tuchagues, J.-P.; Signorella, S. Dalton Trans. 2006, 5156. (b) Biava, H.; Palopoli, C.; Shova, S.; De Gaudio, M.; Daier, V.; González-Sierra, M.; Tuchagues, J.-P.; Signorella, S. J. Inorg. Biochem. 2006, 100, 1660. (c) Daier, V.; Biava, H.; Palopoli, C.; Shova, S.; Tuchagues, J.-P.; Signorella, S. J. Inorg. Biochem. 2004, 98, 1806. (d) Palopoli, C.; González-Sierra, M.; Robles, G.; Dahan, F.; Tuchagues, J.-P.; Signorella, S. J. Chem. Soc., Dalton Trans. 2002, 3813. (e) Palopoli, C.; Chansou, B.; Tuchagues, J.-P.; Signorella, S. Inorg. Chem. 2000, 39, 1458 .

25 Gonçalves, N.S.; Rossi, L. M.; Noda, L. K.; Santos, P. S.; Bortoluzzi, A. J.; Neves, A.; Vencato, I. Inorg. Chim. Acta 2002, 329, 141.

26 (a) Berry, K. J.; Moya, F.; Murray, K. S.; v. d. Bergen, A. M. B.; West, B. O. J. Chem. Soc., Dalton Trans. 1982, 109. (b) Botsivali, M.; Evans, D. F.; Missen, P. H.; Upton, M. W. J. Chem. Soc., Dalton Trans. 1985, 1147.

27 Beauchamps, C.; Fridovich, I. Anal. Biochem. 1971, 44, 276.

28 (a) Durot, S.; Policar, C.; Cisnetti, F.; Lambert, F.; Renault, J.-P.; Pelosi, G.; Blain, G.; Korri-Youssoufi, H.; Mahy, J.-P. Eur. J. Inorg. Chem. 2005, 3513. (b) Liao, Z. R.; Zheng, X. F.; Luo, B. S.; Shen, L. R.; Li, D. F.; Liu, H. L.; Zhao, W. Polyhedron 2001, 20, 2813. 